Article

\title{
At a Microsite Scale, Native Vegetation Determines Spatial Patterns and Survival of Pinus contorta Invasion in Patagonia
}

\author{
Bárbara Langdon ${ }^{1,2, *(\mathbb{C})}$, Lohengrin A. Cavieres ${ }^{2,3}$ and Aníbal Pauchard ${ }^{1,2}$ (i) \\ 1 Laboratorio de Invasiones Biológicas (LIB), Facultad de Ciencias Forestales, Universidad de Concepción, \\ Concepción 4070386, Chile \\ 2 Instituto de Ecología y Biodiversidad (IEB), Santiago 7800003, Chile \\ 3 Departamento de Botánica, Facultad de Ciencias Naturales y Oceanográficas, Universidad de Concepción, \\ Concepción 4070386, Chile \\ * Correspondence: barbaralangdon@gmail.com
}

Received: 8 July 2019; Accepted: 27 July 2019; Published: 2 August 2019

\begin{abstract}
Research Highlights: The invasive species Pinus contorta, has become a new component of the vegetation in the Patagonian Steppe, invading the complex matrix of bare ground, tussock grasses and cushion plants. At a microsite scale, the type of native vegetation is one of the multiple factors determining the establishment of $P$. contort $a$ and in some cases, increasing its survival, and as a result, the invasion of the species. Background and Objectives: The presence of trees, particularly pines, where they are naturally absent, represents a clear threat to Patagonian steppe ecosystems. Thus, understanding the interaction between pines and native plant species may be the key to understanding the invasion and applying management actions. Pinus contorta is considered one of the most aggressive among the pines species, with recognized impacts on regions in the southern hemisphere and Europe, and it is one of the main invaders in the Patagonian steppe. Our aim in this study is to determine the influence of surrounding vegetation on P. contorta spatial distribution, its establishment and future development in the Chilean Patagonia. Materials and Methods: We used point pattern analysis to determine the existence of spatial associations between P. contorta and the resident vegetation of the Patagonian steppe. Further, a seeding experiment was carried out to assess the influence of the surrounding vegetation during $P$. contorta establishment and first growing season. Results: We found that young $P$. contorta individuals are positively associated with the native cushion plant B. magellanica and also to tussock grasses. Seeding experiments showed that P. contorta is influenced by resident plant species during establishment and is able to establish on any ground cover type in the Patagonian steppe, but some resident plant species increase P. contorta survival chances. Conclusions: Pinus contorta is interacting with native vegetation and becoming an active component of the Patagonian steppe mosaic. Although pines can establish in any type of vegetation in the Patagonian steppe mosaics, native cushion and tussock grasses may be facilitating the process and promoting pine survival, allowing it to survive and thrive in this stressful environment.
\end{abstract}

Keywords: Pinus contorta; invasion; facilitation; Patagonia; steppe

\section{Introduction}

Interactions between an invasive species and the resident biota determine the success and impacts of the invasion process [1]. Resident vegetation would influence the number and characteristics of alien species being able to successfully establish, persist and spread in a community [2,3]. The interaction between native vegetation and the invasive species is a spatially explicit process that may occur at multiple scales determining the outcome of the invasion [4,5]. For example, negative interactions, 
such as competition and herbivory could limit invasion [6-8], but positive interactions could have the opposite effect [3,8]. Positive interactions imply that fitness of one species could benefit from better environmental conditions created directly or indirectly by other plants, where this benefit overcomes the costs of living near other plants [9-11].

One of the most frequent positive interactions in invasion ecology is the "facilitative effect" that is given by nursing plant species $[8,12,13]$, where one species provides micro environmental conditions that promote the establishment of invasive species [14,15]. Cushion plants are known for their facilitative conditions, mainly in high elevations [12,16-18]. Given their compact structure and low stature, cushions present the ability to attenuate extreme environmental conditions [19,20], enhancing germination and survival of other, native and non-natives, species [11,21,22]. This is the situation of the Patagonian steppe, a naturally treeless environment, where its vegetation shows a complex system of patches generated by positive and negative interactions, immersed in a matrix of bare ground with minimal vegetation cover [23]. Two patch types dominate the steppe: (a) tussock grasses forming patches in a bare ground matrix and (b) shrubs surrounded by a dense ring of tussock grasses. A cyclical succession model has been proposed to explain these two patch types [23]. In an initial stage, shrubs establish at any location within the bare ground matrix. Once established, they facilitate grass establishment by acting as seed traps and by ameliorating microclimatic conditions (i.e., increasing water availability). Once shrubs start to decay, grass density increases until competition leads to a decrease in its density. As a result, the ring turns into scattered tussock grasses [24]. Patches are the result of a balance between seed distribution and a combination of facilitative and competitive interactions, with each process dominating different phases of the mosaic cycle $[23,25,26]$. To assess the existence of interactions between one or more species in a community, spatial point pattern analysis is considered a standard approach [11,27-29]. Aggregation between species or individuals of interest represents a positive interaction (e.g., facilitation), while repellence represents negative interactions (such as competition) [11,30,31]. In addition to studying spatial patterns, field experiments may help to determine specific mechanisms behind these interactions. Based on both approaches, it may be possible to predict future scenarios of invasions across different resident plant communities.

Pinus contorta Doug. ex Loud. is considered one of the most invasive conifers in the southern hemisphere, especially at higher latitudes and elevations [32-38], and has recently been suggested as a model species for disentangling the mechanisms of the invasion process [39]. It has been reported as naturalized in Russia and as an invader in Australia, Argentina, Chile, Ireland, New Zealand, Sweden, United Kingdom and the United States (outside its natural range) [33,35-37,40-42]. Pinus contorta is a highly shade intolerant species, and is therefore strongly affected by competition during establishment [34], which is why invasion is more likely to occur in open ecosystems [33,43], such as in the case of the Patagonian steppe. The Patagonian steppe is located in the arid-cold south of South America and represents a suitable habitat for $P$. contorta. The low temperatures, scarce precipitation, strong winds, short frost-free periods, and low water availability that characterize this zone make it an extreme environment $[44,45]$. In the harsh conditions of the Patagonian steppe, considerable impacts due to $P$. contorta invasion have already been reported and they are expected to increase in the future [46-50].

The invasion process of $P$. contorta in the Chilean Patagonia, presents the characteristic spatial pattern described for conifers by other authors, mainly due to the wind dispersed seeds, which make the process highly predictable [51,52]. Most seeds fall near the seed source (first hundred meters), generating dense stands with variable age structures. Long distance dispersal is less common, generating lower densities at more distance from the seed source, resulting in scattered trees $[33,35,53]$. In some areas of the Patagonia, invasion densities reach 5000 individuals per hectare (e.g., in exotic grasslands) and around 13,000 individuals per hectare in the steppe near the parent stand. Furthermore, $P$. contorta individuals, in the steppe, can establish hundreds or even thousands of meters away from the parent stand. Although evidence suggests that seed rain (i.e., propagule pressure) is the main driver of P. contorta establishment [52], there is little information about the process determining the success of this 
species at small scales (i.e., microsite) and the potential interactions occurring between this species and the native vegetation. We have then, a unique opportunity to evaluate the invasion process of $P$. contorta at a small spatial scale, determining its spatial patterns, and the potential mechanisms acting to create observed patterns. In this study, we aim to (a) evaluate the spatial patterns of $P$. contorta young stands, (b) assess the existence of spatial associations between P. contorta and the native vegetation, and (c) determine the influence of different native species on the establishment and survival of $P$. contorta during the first growing season.

\section{Materials and Methods}

\subsection{Study Species}

Pinus contorta distributional native range reflects wide ecological amplitude [33,54]. In North America, its native range, the species establishes under a large variety of climatic conditions, spanning a wide range of temperatures (i.e., from $-50{ }^{\circ} \mathrm{C}$ to $35^{\circ} \mathrm{C}$ ) and precipitations (from less than 300 to more than $500 \mathrm{~mm} /$ year). Cone production, with viable seeds, starts at an early age, between 5 and ten years, with the same germination rates as seeds produced by adult trees. Mast seed crops are produced every one or three years and seed size is relatively small compared to other pine species. Germination occurs once there is adequate soil moisture and temperatures are more favorable, resulting in germinating very fast. Pinus contorta resistance to frost is relatively high, allowing it to survive where other species do not [54]. All of these characteristics, namely small seeds, short juvenile period (early seed production), common mast seed crops and fast germination rates, are key determinants of the invasive potential of pine species, as they give $P$. contorta the ability to disperse long distances, overcome competition with other species and to survive under the disturbance regime in the invaded community [41].

\subsection{Study Area}

To determine the spatial pattern of $P$. contorta and its potential association with native vegetation, we selected an invaded area located in Coyhaique Alto (45 $30^{\prime} \mathrm{S}$ and $\left.71^{\circ} 42^{\prime} \mathrm{W}\right), 36 \mathrm{~km}$ east from Coyhaique City in the Aysén Region (Figure 1). Coyhaique Alto is part of the Cold Steppe Ecoregion [44], and it is characterized by low temperatures (mean annual temperature of $6.5^{\circ} \mathrm{C}$, mean maximum temperature of $11.2^{\circ} \mathrm{C}$ and mean minimum temperature of $2.2^{\circ} \mathrm{C}$ ) and annual precipitation ranging from 400 to $700 \mathrm{~mm} /$ year, and a short growing season free of snow (39 frost free days) [55]. Further, the harsh conditions of the cold steppe are also characterized by a six month period of water stress with a winter dormancy period of 9.1 months [45].

Patagonian steppe vegetation is dominated by scattered low stature native tussock grass species, mainly belonging to genera Festuca, Agrotis, Stipa, Poa, and Bromus [44]. We will refer to those species as tussock grasses. Prostrate shrub species with a dense canopy such as Baccharis sp., Oreopolus glacialis (Poepp.) Ricardi, Mulinum spinosum Pers., and Acaena sp. are also common species in the Patagonian steppe [44] and may form solid vegetation patches commonly described as cushions. Baccharis magellanica (Lam.) Persoon is a creeping perennial shrub, which forms hemispheric cushions up to $40 \mathrm{~cm}$ tall and $1.5 \mathrm{~m}$ diameter. Oreopolus glacialis is a perennial cushion plant, which grows in sandy soils in Chile and Argentina. It has been previously described as a nurse plant [18,22]. Mulinum spinosum is a spiny shrub, which forms rounded shrubby cushions up to $50 \mathrm{~cm}$ in diameter. Acaena integerrima Gillies ex Hook. Et Arn. is a perennial prostrate shrub no more than $15 \mathrm{~cm}$ height and 15-22 cm diameter. It is common to find plantations of exotic species in Patagonia. Most of them are P. contorta, Pinus sylvestris L., Pinus ponderosa Douglas ex C. Lawson, and Pseudotsuga menziesii (Mirb.) Franco. During the 1970s they were established for erosion control purposes after large extensions of land were affected by fires [56], but after a few years, commercial plantations were also established. 


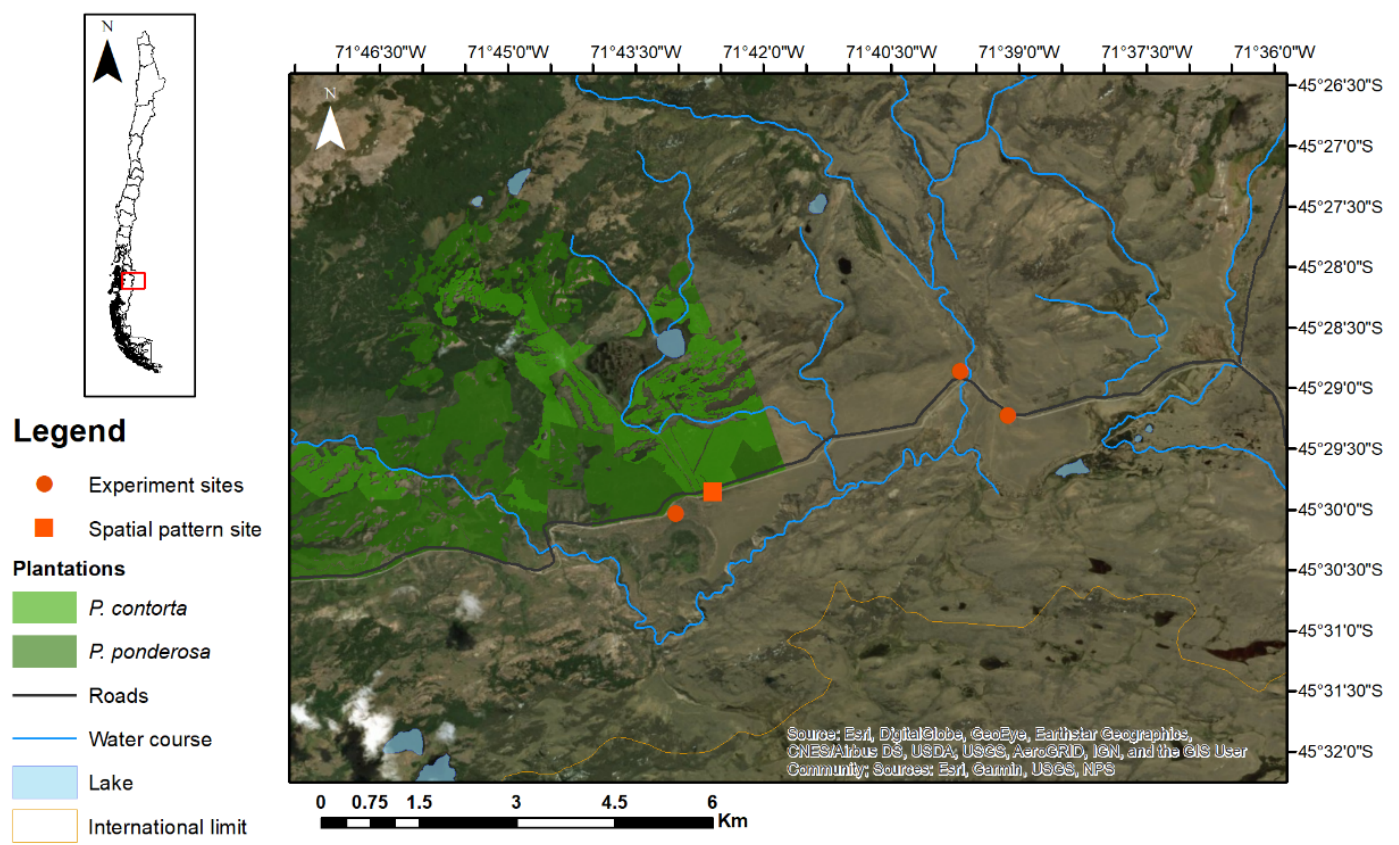

Figure 1. Study area showing the four study sites in the Patagonia steppe of Chile.

\subsection{Spatial Associations with Native Vegetation}

To determine the microsite-scale spatial pattern of $P$. contorta wildings originated from an established commercial plantation in Coyhaique Alto, we established two $20 \times 20 \mathrm{~m}$ square plots separated by $20 \mathrm{~m}$ (Figure 2). Each plot was divided into $25 \mathrm{~cm}\left(0.0625 \mathrm{~m}^{2}\right)$ quadrats, resulting in a sampling grid of 6400 quadrats. Both plots were established perpendicular to the plantation edge, starting at $50 \mathrm{~m}$ from the plantation. In each one of the small quadrants we determined the presence of seven ground cover types, which could consist of a single species or a group of them: P. contorta, tussock grasses, bare ground, B. magellanica, O. glacialis, A. integerrima and M. spinosum. For every $P$. contorta individual we recorded the total height, diameter at collar height $(\mathrm{DCH})$, crown diameter, and the exact position of the stem, in order to recognize on which ground cover type the individual germinated and established. Pinus contorta individuals were classified into five categories, based on total height, as a proxy of their age: pines under $10 \mathrm{~cm}$ height, between 11 and $40 \mathrm{~cm}$, between 41 and 100 and more than $100 \mathrm{~cm}$ height. An extra fifth category was all pines more than $41 \mathrm{~cm}$ height.

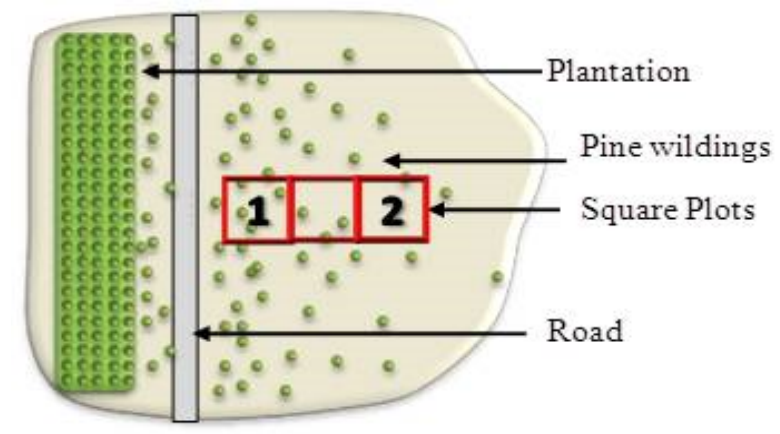

Figure 2. Location and design of the sampling plots in the study site. Each square plot $(20$ by $20 \mathrm{~m})$ is subdivided in a grid of $0.25 \mathrm{~m}\left(0.0625 \mathrm{~m}^{2}\right)$ quadrats.

In order to test for spatial associations, we used spatial pattern analyses, which has been widely used in plant ecology to study the existence of interactions between species $[11,27,29,30,57,58]$. In recent years, the use of O-ring statistics in the study of plant spatial patterns and plant-plant interactions has increased [59-62]. Here, the position of a plant is represented as a point and this method 
analyzes the spatial distribution of such points to determine whether they are randomly distributed or aggregated. According to this analysis, spatial aggregation between species or individuals of interest represents a positive interaction (e.g., facilitation), while repellence will represent negative interactions (e.g., competition) [11,30,31]. The O-ring statistic uses rings at given distances from the point of interest, so that the spatial relation between points can be related to a certain scale [63]. When using grids, instead of points, the estimator $\mathrm{O}_{l m}(\boldsymbol{r})$ corresponds to the probability of finding a cell of category $m$ at a distance $\boldsymbol{r}$ away from a cell of category $\boldsymbol{l}$ [64]. We used the software Programita [63] and the O-Ring statistic of point pattern analysis to analyze spatial patterns between $P$. contorta individuals and the vegetation of the Patagonian steppe. First, for the analyses, a new ground cover type, "Cushions", was created considering B. magellanica, A. integerrima, O. glacialis and M. spinosum together. As our ground cover types could not be represented by points, we considered the grid-based approach of Wiegand et al. [62] to deal with plants of finite size and irregular shape, and thereby represent the actual cover of each ground cover type. Then, two types of analyses were done: (a) univariate analyses, considering $P$. contorta individuals or each ground cover type alone, for which we hypothesized Complete Spatial Randomness (CSR), and (b) bivariate analyses, where P. contorta individuals were analyzed against each ground cover type. In this case, we used the antecedent conditions model, randomizing the pine category of interest, and fixing the position of the observed cover types [63].

Considering that there were no environmental gradients between both plots (Figure 3), and in order to increase the power of the analyses, we considered both plots as two areas inside one larger plot. To represent this approach correctly in the software, we used the "irregularly shaped study region" option. The analysis of statistical significance was evaluated using 99 Monte Carlo simulations $[62,63,65]$. Cushions, grasses and bare soil were represented in cells, where each plant could occupy one or more cells, depending on shape and size. This method restricts plants of the same cover type to overlap but does allow for plants of different cover types to do it.

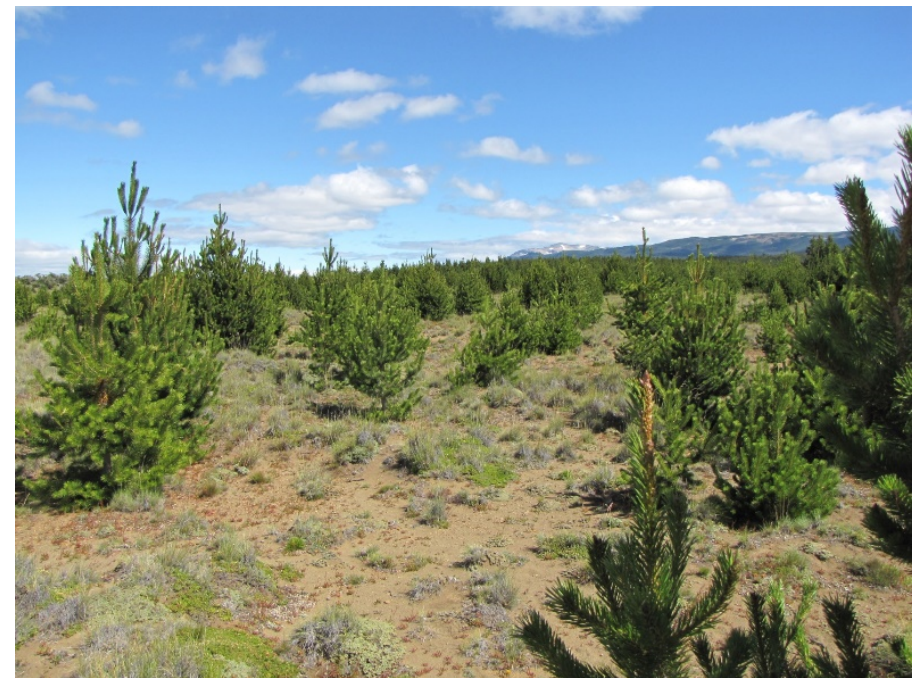

Figure 3. Invaded area selected to determine the influence of surrounding vegetation on Pinus contorta, located in the Patagonian Steppe of Coyhaique Alto $\left(45^{\circ} 30^{\prime} \mathrm{S}\right.$ and $\left.71^{\circ} 42^{\prime} \mathrm{W}\right)$.

\subsection{Pinus contorta Establishment and Survival}

We selected three non-invaded areas (Figure 4), between one and six $\mathrm{km}$ apart from each other, to determine the potential influence of native vegetation on $P$. contorta establishment and survival (Site 1: $45^{\circ} 30^{\prime} 247^{\prime \prime} \mathrm{S}, 71^{\circ} 42^{\prime} 815^{\prime \prime} \mathrm{W}$, Site 2: $45^{\circ} 29^{\prime} 312^{\prime \prime} \mathrm{S}, 71^{\circ} 38^{\prime} 964^{\prime \prime} \mathrm{W}$, and site $\left.3: 45^{\circ} 28^{\prime} 991^{\prime \prime} \mathrm{S}, 71^{\circ} 39^{\prime \prime} 531 \mathrm{~W}\right)$. 


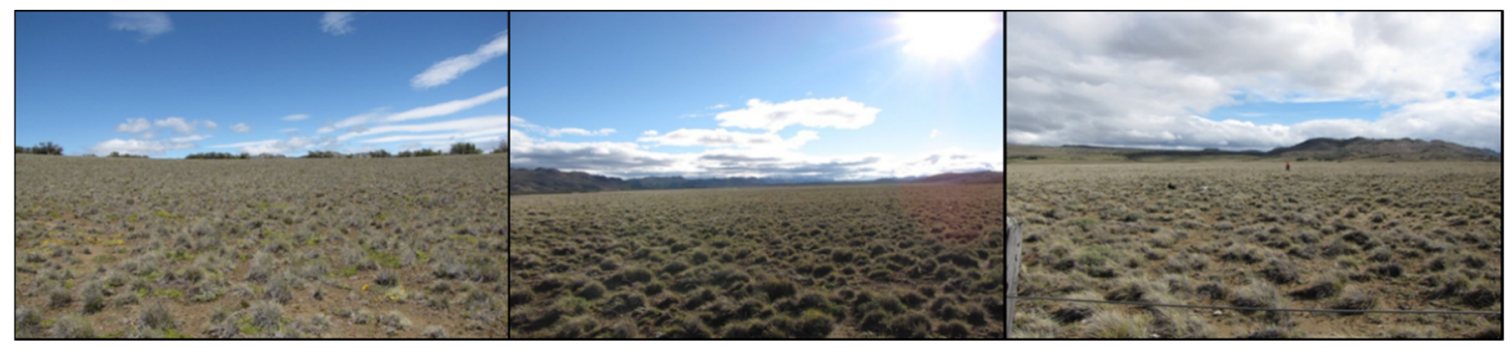

Figure 4. Photographs of the three sites at the Patagonian Steppe, where Pinus contorta survival and establishment experiments were established. They were located at 1.6, 3.5 and $4.7 \mathrm{~km}$ from the plantation, approximately.

To determine the influence of adjacent vegetation during the early establishment of P. contorta, we sowed $P$. contorta seeds on the most abundant ground cover types: A. integerrima, O. glacialis, B. magellanica, tussock grasses and bare ground (Figure 5). In each of the three sites we established 20 experimental units (EU) formed by small plots dominated by a determined ground cover type, in each one of the five ground cover types. Fifty seeds were sown in each one of the EU. Because of the low presence B. magellanica, this species was considered in only one of the sites. Therefore, we established 80 $\mathrm{EU}$ in two of the sites (20 in each of the four present ground cover types) and $100 \mathrm{EU}$ ( 20 in each of the five ground cover types) in the remaining site. Seeds were sowed during May 2010, before winter, and were placed on the different ground cover types without covering them, to replicate natural conditions after seed fall. Seed material, previously collected in the region, was purchased from the CONAF of the Aysén Region. The number of seedlings that emerged and remained alive between recording periods was registered fortnightly during the growing season, starting in December 2010 to May 2011.
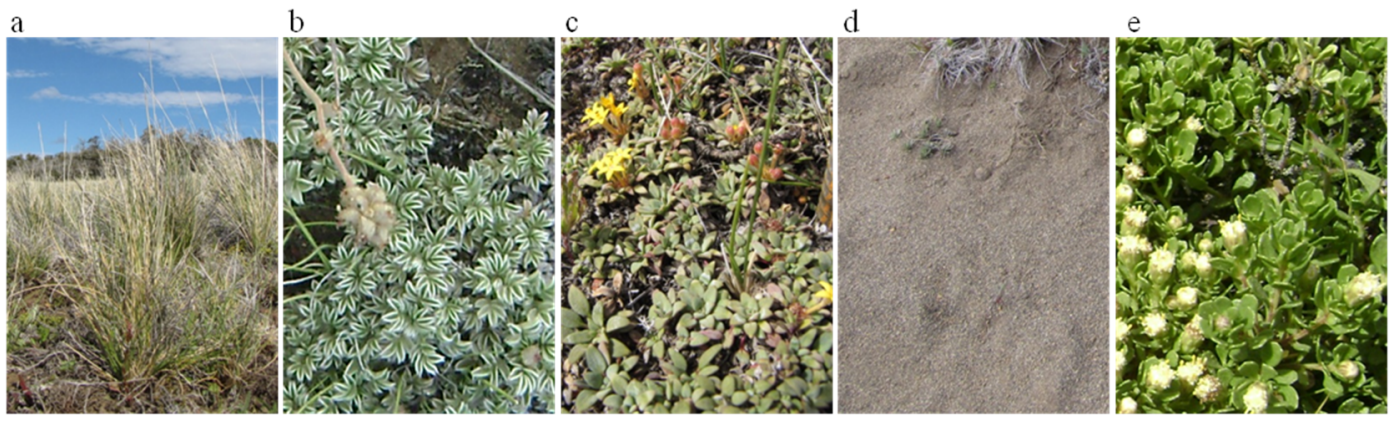

Figure 5. The five ground cover types considered in the study: (a) tussock grasses, (b) Acaena integerrima, (c) Oreopolus glacialis, (d) bare ground, and (e) Bacharis magellanica. Pinus contorta can establish itself in any of these substrates.

We used repeated measures ANOVA to assess differences in early establishment between and within ground cover types. During the growing season (December to May), the number of living seedlings was registered nine times. To address the lack of replication for B. magellanica, two data sets were created considering the percentage of living seedlings (of a total of 50 sown seeds). Therefore, two analyses were conducted: one for the four substrates present in the three study sites (considering the study sites as a block), and the second one for the five substrates present in site 1. We used the MIXED procedure, the most appropriate matrix of variance-covariance, and the REPEATED instruction in SAS Software V9. The covariance structure was determined based on the Akaike Coefficient, according to which the nearest value to zero will be the most appropriate. When significant differences were detected, means were compared using Tukey Tests under the LSMEANS instruction. Graphs were made using SPSS. 


\section{Results}

\subsection{Spatial Associations with Native Vegetation}

Mean pine density was 2950 trees per hectare with a ground cover of $20.7 \%$ (Figure 6). Mean diameter at collar height was of $26.21 \mathrm{~mm}$ with a crown diameter of $54.16 \mathrm{~cm}$ and a mean height $103.2 \mathrm{~cm}$. A total of 236 trees were sampled with all height classes being represented (Table 1).
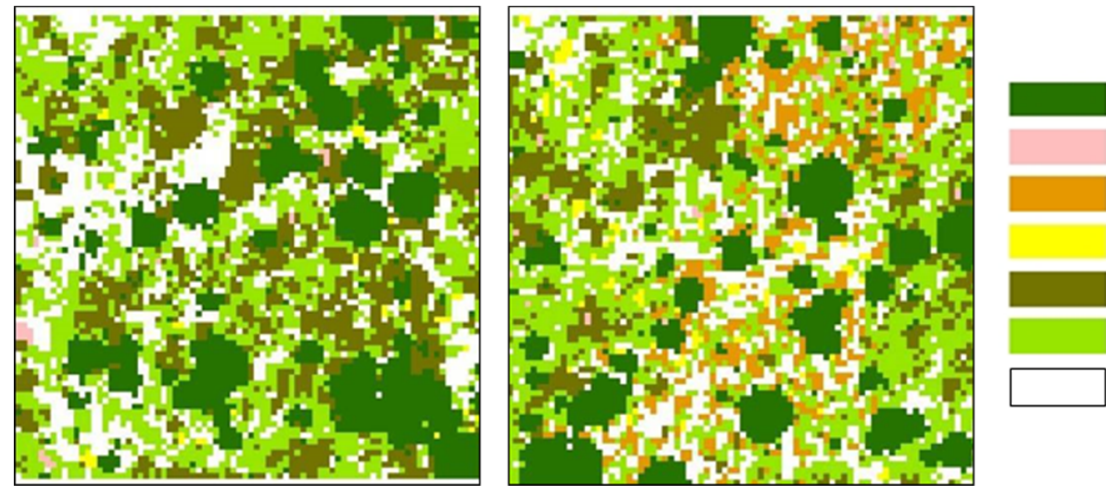

\section{P. contorta \\ M. spinosum \\ O. glacialis \\ A. integerrima \\ B. magellanica \\ Tussock grasses \\ Bare ground}

Figure 6. Ground cover types represented in the two areas of the sampling plot: Pinus contorta (22.5\% and $18.9 \%)$, B. magellanica ( $30.8 \%$ and $16.2 \%)$, Tussock grasses (53.7\% and $58.1 \%)$, bare ground $(69.9 \%$ and $74.8 \%)$, Acaena integerrima (1\% and $1.8 \%)$, Oreopolus glacialis $(0.1 \%$ and $12.8 \%)$, and Mulinum spinosum $(0.5 \%$ and $0.7 \%)$.

Table 1. Morphological attributes of Pinus contorta individuals sampled in the invaded area.

\begin{tabular}{ccccc}
\hline Height Class & $\mathbf{n}$ & Height $(\mathbf{c m})$ & DCH $^{*}(\mathbf{m m})$ & Crown Diameter $(\mathbf{c m})$ \\
\hline$<10 \mathrm{~cm}$ & 44 & 7.49 & 6.625 & 10.86 \\
$11-40 \mathrm{~cm}$ & 77 & 20.46 & 10.53 & 18.25 \\
$41-100 \mathrm{~cm}$ & 30 & 70.30 & 21.88 & 48.54 \\
$>100 \mathrm{~cm}$ & 85 & 229.60 & 65.80 & 138.98 \\
$>41 \mathrm{~cm}$ & 115 & 188.16 & 54.33 & 115.44 \\
Total & $236^{* *}$ & $103.20^{* * *}$ & $26.21^{* * *}$ & $54.16^{* * *}$ \\
\hline
\end{tabular}

${ }^{*}$ Diameter at collar height. ${ }^{* *}$ Corresponds to the total number of $P$. contorta individuals registered in the two sampling plots. ${ }^{* *}$ Corresponds to the mean value of the attribute for all individuals registered in the two plots.

Most abundant cover types in the area were bare ground (72.4\%), followed by tussock grasses (57.5\%) and B. magellanica (23.5\%). Given the low cover of A. integerrima $(1.4 \%)$, O. glacialis (6.45\%), and $M$. spinosum $(0.6 \%)$, they were not taken into account by themselves for further analysis (only in the "cushions" ground cover type).

Univariate analysis showed an aggregated spatial pattern for the three main ground cover types: B. magellanica, cushions, and tussock grasses (Figure 7a). Those patches are surrounded by a bare ground matrix. The univariate analysis done for $P$. contorta height classes showed that smaller pines $(<10 \mathrm{~cm}$ height) did not differ from the Complete Spatial Randomness model. Individuals between 11 and $40 \mathrm{~cm}$ height showed an aggregated distribution in the first $25 \mathrm{~cm}$ of distance, whereas individuals between 41 and $100 \mathrm{~cm}$, or more than $100 \mathrm{~cm}$ height, did not present differences with the Complete Spatial Randomness (Figure $7 \mathrm{~b}$ ).

Bivariate analyses indicated no aggregation of $P$. contorta individuals $(11-40 \mathrm{~cm})$ around other pine height classes $(>41 \mathrm{~cm}, 41-100 \mathrm{~cm},>100 \mathrm{~cm})$, showing that pine individuals are not aggregated around older or taller pine individuals. Regarding the other ground cover types, 11 to $41 \mathrm{~cm} \mathrm{height}$ pines showed a significant aggregation up to $50 \mathrm{~cm}$ with the native cushion $B$. magellanica and up to $25 \mathrm{~cm}$ with tussock grasses (Figure 8). 


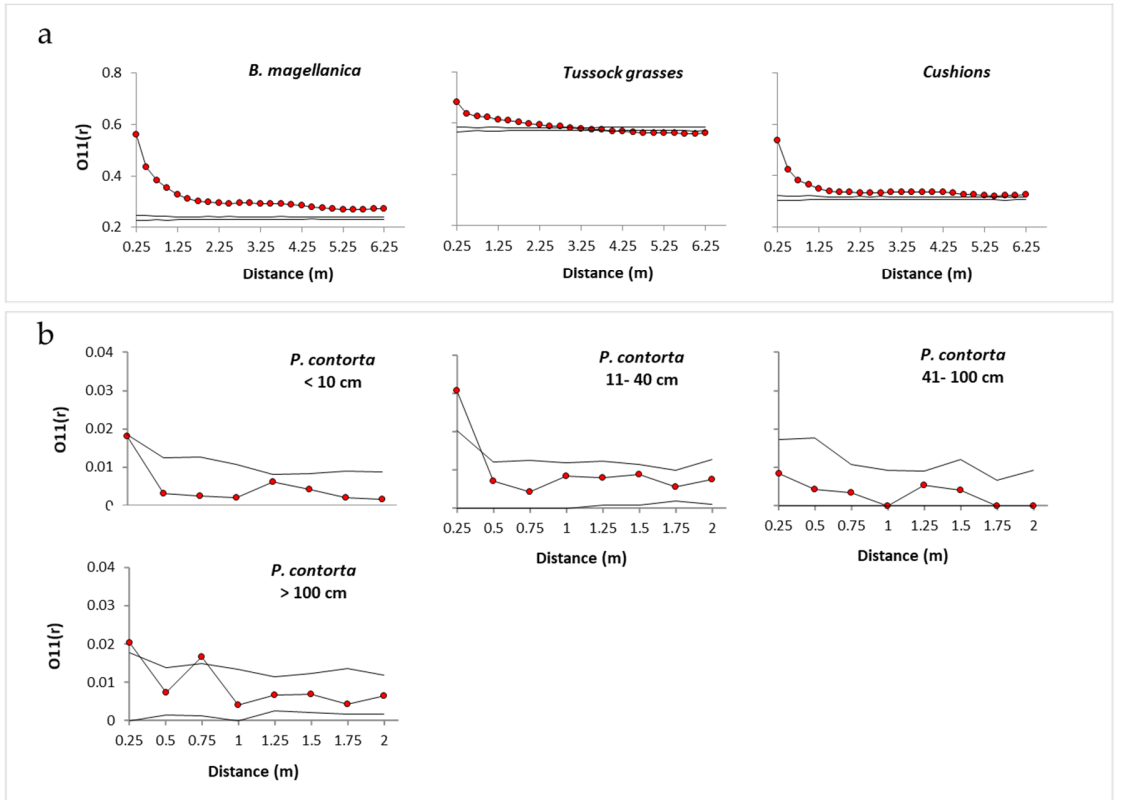

Figure 7. O-ring statistics for the spatial distribution of (a) the three substrates: B. magellanica, tussock grasses, cushion plants, and (b) each Pinus contorta height class. The O11(r) estimator indicates the probability of finding a cell of the same category 1 at a distance $r$ (shown in y axis) away from a cell of another cell of category 1. Continuous lines represent confidence envelopes from the 99 Monte Carlo simulations. If the O-ring function (red dots) exceeds the upper confidence level, it indicates an aggregated pattern of the species or plants involved. If the function locates below the lower confidence interval, then it indicates a repulsion or regularly spatiated distribution of the plants. If the function is located between both confidence intervals, then the distribution of the plants does not differ from the Complete Spatial Randomness (CSR) pattern.

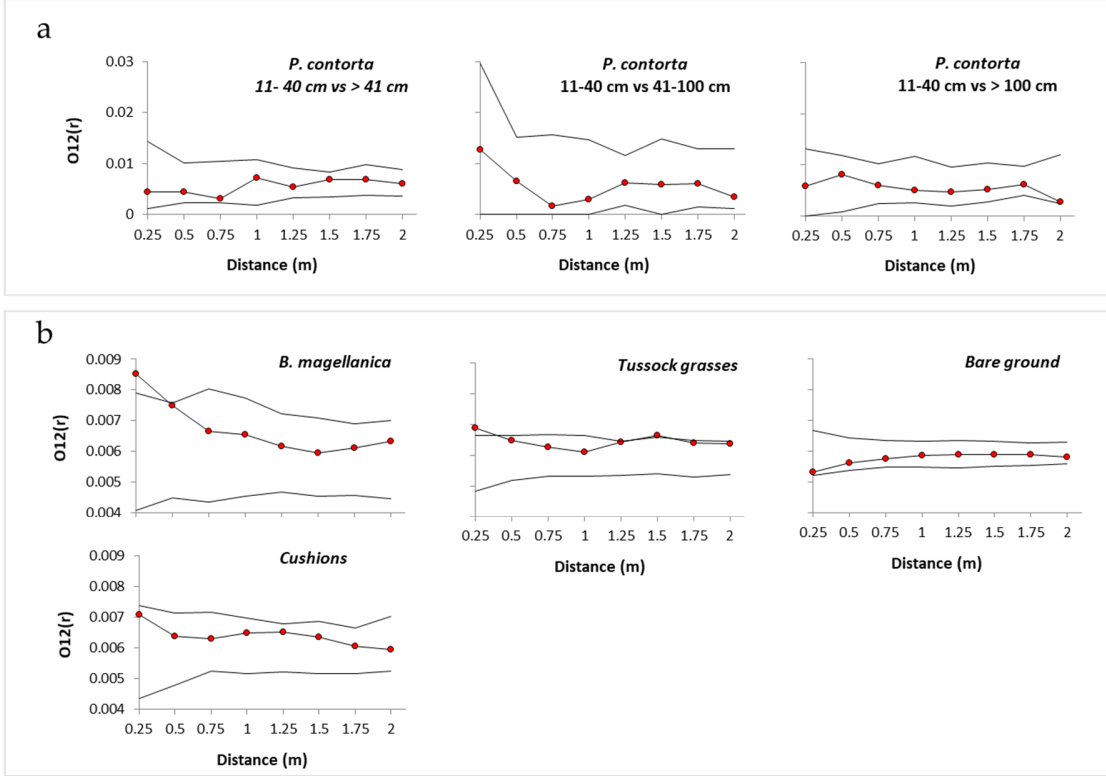

Figure 8. Spatial distribution patterns between (a) different Pinus contorta height classes and (b) Pinus contorta seedlings of 11 to $40 \mathrm{~cm}$ height and each ground cover type: $B$. magellanica, tussock grasses, bare ground, and cushions. The O12(r) estimator indicates the probability of finding a cell of category 2 at a distance raway from a cell of category 1 . Continuous lines represent confidence envelopes from the 99 Montecarlo simulations. If the O-ring function (red dots) exceeds the upper confidence level, it indicates an aggregated pattern of the species or plants involved. If the function locates below the lower confidence interval, then it indicates a repulsion or regularly spatiated distribution of the plants. If the function is located between both confidence intervals, then the distribution of the plants does not differ from the CSR pattern. 


\subsection{Pinus contorta Establishment and Survival}

Ground cover type, block (sites), and their interaction significantly affected the proportion of sown seeds that emerged as seedlings, and that survived the entire growing season in each EU (Table 2).

Table 2. Repeated measures ANOVA for the proportion of sowed seeds that emerged as seedling and survived the entire growing season at three sites in Coyhaique (nine measurements for each experimental sites).

\begin{tabular}{cccc}
\hline & DF & F-Value & Pr $>$ F \\
\hline Site & 2 & 4.41 & 0.0133 \\
Substrate & 3 & 6.28 & 0.0004 \\
Site $\times$ Substrate & 6 & 6.12 & $<0.0001$ \\
interaction & & & \\
\hline
\end{tabular}

The repeated measures ANOVA showed significant differences between ground cover types. Overall, the percentage of surviving seedlings was low, with the highest percentage recorded on the bare ground of site $3(4.43 \%)$, followed by 0 . glacialis in site $1(2.43 \%)$. The lowest percentage of survived seedlings $(0.21 \%)$ was recorded on the Tussock grasses of site 3 , although it did not differ from the rest of the cover types in the three sites (Figure 9a). When comparing between the five ground cover types present in site 1, we found no significant differences between them (Figure 9b).

a

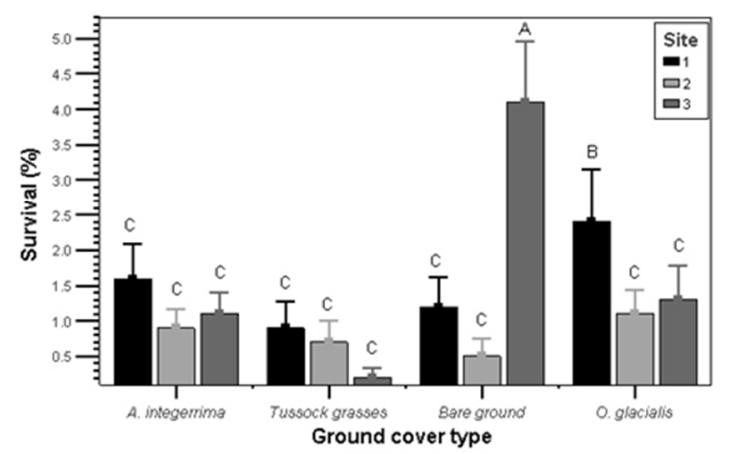

b

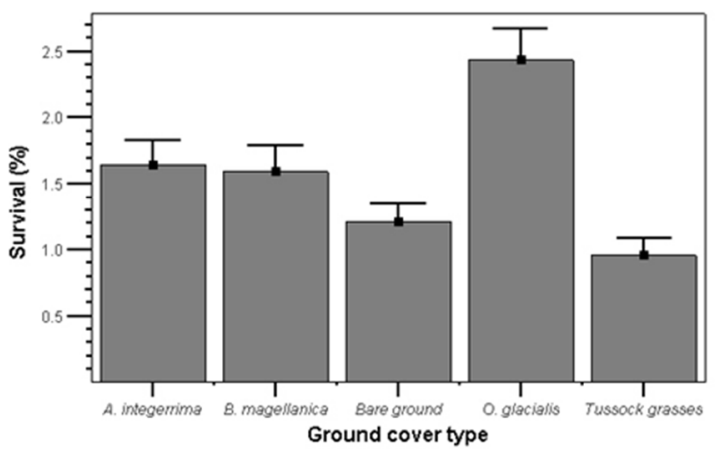

Figure 9. Survival (\%) of emerged seedling of the 20 Experimental Units established on each ground cover type in three study sites. Because of the lack of replication for Baccharis magellanica in site 1, results were derived from two analyses: (a) Seedling survival (\%) on each one of the four ground cover types present in the three study sites and (b) mean survival (\%) on each ground cover type in site 1 (including B. magellanica).

\section{Discussion}

A multiscale approach can help to understand the mechanisms acting behind successful invaders [4]. While at larger scales $P$. contorta presented in Patagonia the characteristic pattern of a pine invasion process without limitations other than seed availability [51] or the limited relationship with microsite heterogeneity [52], our results show that new patterns arise at smaller microsite scales, which may be attributed to other underlying processes. Previous work indicated that, in the Chilean Patagonia, the $P$. contorta invasion front is characterized by high densities of young individuals with scarce adult trees, all randomly distributed [51]. In other words, recruitment occurs at any distance from the seed source, without a clear trend. However, our results show that at smaller scales $P$. contorta does have higher recruitment in certain microsite conditions, and that interactions with the native vegetation could be driving specific processes during seedling recruitment and survival, ultimately influencing the invasion patterns. 
Our results indicate that Pinus contorta spatial distribution in the Patagonian steppe, at a microsite scale, shows an aggregated pattern for young individuals, but no association (i.e., facilitative interactions) between them and adult pine trees was found. Young pines (between 11 and $40 \mathrm{~cm}$ height) were associated with the native cushion B. magellanica and tussock grasses within the first $25 \mathrm{~cm}$ around them, suggesting that facilitative interactions could be involved in the spatial distribution of the species in our study site. It is well-known that some plants provide micro-environmental conditions which promote the establishment of other species either by regulating stress (by decreasing negative environmental factors such as herbivory, high temperatures or high radiation) or by increasing resources availability [66]. This phenomenon (i.e., nurse-plant effect [14,15]), is especially frequent in stressful environments, such as the Patagonian steppe [66].

Ledgard [67] affirmed that the successful spread of invasive conifers depends on the availability of safe sites, and the best sites for conifer establishment then, are those with a spare vegetation cover, where competition levels are still low $[67,68]$. Our sowing experiments results are in line with this, showing that positive interactions with the native B. magellanica or tussock grasses are not exclusive. Depending on site conditions, other species could have the same effect on pine establishment, probably due to better environmental conditions beneath its cover. These better conditions can be met, in this case, on bare ground in one site or within the compact cushion plant O. glacialis in another site. Allen and Lee [69] reported similar results in tussock land in New Zealand, where $P$. contorta establishment occurs both between or beneath tussock canopies, indicating that benefits from shelter, mainly against dissection and frost, may offset the disadvantages of competition with tussock grasses. Bare ground, bryophytes and lichens have been identified as the most preferred microsites for P. contorta establishment, followed by microsites dominated by rosettes and loose mats [69]. The least preferred microsites would be those with high cover of densely rhizomatous, sward-forming or tussock grasses species [69].

Although there is evidence of positive interactions of young pines and the native vegetation, smaller pine seedlings (less than $10 \mathrm{~cm}$ tall) showed a random spatial pattern, indicating no facilitative effects from native vegetation at such early stages. Changes in the balance of interactions are expected with time, as both involved species get through different life stages [70]. The association with B. magellanica and tussock grasses appears after two or three growing seasons, when seedlings are between 11 and $40 \mathrm{~cm}$ tall. A few years later the association is lost again, when saplings are more than $41 \mathrm{~cm}$ tall. Thus, although native species could have some positive effects on $P$. contorta during its germination and establishment, the interaction balance is not constant, and it changes at the time plants grow and pass through different life stages [71]. In some cases, plants that were facilitated at their first stages of growth could enhance their performance and compete or even suppress their nurse plant in advanced stages $[66,72]$. These differences between life stages indicate that $P$. contorta seed germination occurs anywhere in the invasion front, but establishment and survival will be affected by the ground cover type during the first growing seasons. We still do not know which interaction dominates when adult pines are present, and it is too early to determine what happens when the pine canopy closes, but it is clear that although facilitation does not seem to be crucial for the establishment of $P$. contorta in the Patagonian steppe, it certainly influences its spatial patterns.

When the interaction balance during early establishment changes from facilitation to competition, interactions become one of the main prevention and control techniques described for invasive confers. The effects that competition with fast growing herbs and small shrubs has on conifers establishment [34] has become one of the main control actions in New Zealand. Sowing and fertilizing around forests margins will limit the spread of $P$. contorta or other conifers $[67,68,73]$. Benecke [32] determined that $P$. contorta does not survive more than 18 months in managed pastures, while $94 \%$ of sowed $P$. contorta individuals survived after 2 years on unmanaged pastures. The Patagonian steppe is a natural ecosystem, where fertilization, seeding or irrigation does not occur, increasing the risk of future spreading.

Degradation of the native vegetation in the Patagonian Steppe may be facilitating the invasion of pines. The native undisturbed vegetation of the Chilean Patagonia is composed of dense tussock 
grasses, herbs, and shrubs patches immersed in a bare ground matrix, as has been reported for the same ecosystem in Argentina [25]. In our study site Coyhaique Alto, groundcover of tussock grasses is similar to that reported in the literature for the region (between 50 and $55 \%$ according to Hepp [44]), but the surface of the bare ground is much higher. While in our study we found $72.4 \%$ for the total cover of bare ground, values in the literature indicated 25 to $42 \%$ of bare ground cover [44]. According to Hepp [44], one of the main causes for this difference could be a high stocking rate, which leads to a decrease of tussock cover in the steppe. Although it is hard to demonstrate, it has been reported that natural vegetation of the Patagonian steppe was originally dominated by grasses, and due to human-related disturbances, tussock cover decreased and new species such as shrubs or cushions arrived in the system [25]. Therefore, inadequate management and overgrazing by livestock and introduced hare, could be leading to an increase in shrubs and some herbaceous species such as Acaena spp. and M. spinosum, previously absent in the steppe [44,45]. If cushion plants and shrubs continue to increase their cover and bare ground is exposed due to heavy grazing, the susceptibility of the steppe to pine invasion could increase even more.

\section{Conclusions}

Pinus contorta has become a new component in the mosaic system of the Patagonian steppe invading across a diversity of microsite conditions. In this study, we have found that this invasive pine species could be facilitated by cushion species and tussock grasses during early stages. Although these positive interactions apparently turn to competition at later stages, they could be promoting pine survival in the harsh conditions of the Patagonian steppe, as it has been shown in other examples where facilitative interactions allowed the presence of alien invasive species in stressful environments (e.g., [12,22]). Tussock grasses show no resistance to P. contorta invasion, making the Patagonian steppe an even more susceptible environment. Thus, more strict preventive measurements should be taken, when establishing new pine plantations in the steppe of Chile and Argentina. In addition, for Pinus control, active management should be implemented before large extensions of the Patagonian steppe are invaded. The results presented here and in the broader literature on pine invasions should be seriously considered in such management actions.

Interactions with the resident biota should be taken into account when assessing the mechanisms behind successful invaders. Despite the attributes which may give certain species a high invasive potential, the resident biota of the invaded area will determine which species establishes and to what extent. This information may prove critical when controlling invasive plants and when restoring natural vegetation, especially to reduce reinvasion of the site. A combination of multiscale observational approaches and simple experiments may shed light into both patterns and mechanisms to uncover the reciprocal effects of the interactions between native vegetation and the invasive species.

Author Contributions: Conceptualization, B.L., A.P. and L.A.C.; Data curation, B.L.; Formal analysis, B.L.; Funding acquisition, B.L. and A.P.; Investigation, B.L.; Methodology, B.L. and A.P.; Project administration, B.L.; Resources, B.L. and A.P.; Software, B.L.; Supervision, A.P. and L.A.C.; Validation, B.L., A.P. and L.A.C.; Visualization, B.L.; Writing—original draft, B.L.; Writing—review and editing, B.L., A.P. and L.A.C.

Funding: Bárbara Langdon PhD was funded by CONICYT. The research was funded by FONDECYT 1100792, ICM P05-002, and Proyecto Conicyt PIA Apoyo CCTE AFB170008, and was conducted in the Laboratorio de Invasiones Biológicas (LIB).

Acknowledgments: We would like to thank Alberto Galilea and Juan Carrasco for allowing us to do all the experiments and sampling on their land. We also would like to thank Alejandra Jimenez, Carolina García and Jocelyn Esquivel for their help in the field work. Kirk Moloney provided statistical guidance for the spatial analysis.

Conflicts of Interest: The authors declare no conflict of interest. The funders had no role in the design of the study; in the collection, analyses, or interpretation of data; in the writing of the manuscript, or in the decision to publish the results. 


\section{References}

1. Vila, M.; Weiner, J. Are Invasive Plant Species Better Competitors than Native Plant Species? Evidence from Pair-Wise Experiments. Oikos 2004, 105, 229-238. [CrossRef]

2. Tilman, D. Niche Tradeoffs, Neutrality, and Community Structure: A Stochastic Theory of Resource Competition, Invasion, and Community Assembly. Proc. Natl. Acad. Sci. USA 2004, 101, 10854-10861. [CrossRef] [PubMed]

3. Alpert, P.; Bone, E.; Holzapfel, C. Invasiveness, Invasibility and the Role of Environmental Stress in the Spread of Non-Native Plants. Perspect. Plant Ecol. Evol. Syst. 2000, 3, 52-66. [CrossRef]

4. Pauchard, A.; Shea, K. Integrating the Study of Non-Native Plant Invasions across Spatial Scales. Biol. Invasions 2006, 8, 399-413. [CrossRef]

5. Pauchard, A. Conservation Research in Invasions as Spatially Explicit Processes. Front. Ecol. Environ. 2007, 5, 123-124.

6. D'Antonio, C.; Mahall, B. Root profiles and competition between the invasive, exotic perennial, carpobrotus edulis, and two native shrub species in california coastal scrub. Am. J. Bot. 1991, 78, 885-894. [CrossRef]

7. D'Antonio, C.M. Mechanisms Controlling Invasion of Coastal Plant Communities by the Alien Succulent Carpobrotus Edulis. Ecology 1993, 74, 83-95. [CrossRef]

8. Richardson, D.M.; Ek, P.P.Y.S.; Rejmánek, M.; Barbour, M.G.; Panetta, F.D.; West, C.J. Naturalization and invasion of alien plants: Concepts and definitions. Divers. Distrib. 2000, 6, 93-107. [CrossRef]

9. Callaway, R. Positive Interactions among Plants (Review). Bot. Rev. Posit. Interact. Plants 1995, 61, $306-349$.

10. Bruno, J.F.; Stachowicz, J.J.; Bertness, M.D.; Bertness Mark, D.; Bruno John, F.; Stachowicz John, J. Inclusion of Facilitation into Ecological Theory. Trends Ecol. Evol. 2003, 18, 119-125. [CrossRef]

11. Fajardo, A.; Quiroz, C.L.; Cavieres, L.A. Spatial Patterns in Cushion-Dominated Plant Communities of the High Andes of Central Chile: How Frequent Are Positive Associations? J. Veg. Sci. 2008, 19, 87-96. [CrossRef]

12. Cavieres, L.A.; Quiroz, C.L.; Molina-Montenegro, M.A.; Muñoz, A.A.; Pauchard, A. Nurse Effect of the Native Cushion Plant Azorella Monantha on the Invasive Non-Native Taraxacum Officinale in the High-Andes of Central Chile. Perspect. Plant Ecol. Evol. Syst. 2005, 7, 217-226. [CrossRef]

13. Brooker, R.W.; Maestre, F.T.; Callaway, R.M.; Lortie, C.L.; Cavieres, L.A.; Kunstler, G.; Liancourt, P.; Tielbörger, K.; Travis, J.M.J.; Anthelme, F.; et al. Facilitation in Plant Communities: The Past, the Present, and the Future. J. Ecol. 2008, 96, 18-34. [CrossRef]

14. Franco, A.; Noble, P. Interactions Between Seedlings of Agave Deserti and the Nurse Plant Hilaria Rigida. Ecology 1988, 69, 1731-1740. [CrossRef]

15. Franco, A.; Nobel, P. Effect of Nurse Plants on the Microhabitat and Growth of Cacti. J. Ecol. 1989, 77, 870-886. [CrossRef]

16. Journal, S.; Aug, N.; Mary, T.K. Nurse Effect of Bolax Gummifera Cushion Plants in the Alpine Vegetation of the Chilean Patagonian Andes. J. Veg. Sci. 2016, 13, 547-554.

17. Cavieres, L.A.; Badano, E.I.; Sierra-Almeida, A.; Molina-Montenegro, M.A. Microclimatic Modifications of Cushion Plants and Their Consequences for Seedling Survival of Native and Non-Native Herbaceous Species in the High Andes of Central Chile. Arct. Antarct. Alp. Res. 2007, 39, 229-236. [CrossRef]

18. Nuñez, C.I.; Aizen, M.A.; Ezcurra, C. Species Associations and Nurse Plant Effects in Patches of High-Andean Vegetation. J. Veg. Sci. 2006, 10, 357-364. [CrossRef]

19. Bertness, M.D.; Callaway, R. Positive Interactions in Communities. Trends Ecol. Evol. 1994, 9, $191-193$. [CrossRef]

20. Brooker, R.W.; Callaghan, T.V. The Balance between Positive and Negative Plant Interactions and Its Relationship to Environmental Gradients: A Model. Oikos 1998, 81, 196-207. [CrossRef]

21. Cavieres, L.A.; Fajardo, A. Browsing by Guanaco (Lama Guanicoe) on Nothofagus Pumilio Forest Gaps in Tierra Del Fuego, Chile. For. Ecol. Manag. 2005, 204, 237-248. [CrossRef]

22. Badano, E.; Villarroel, E.; Bustamante, R.O.; Marquet, P.A.; Cavieres, L.A. Ecosystem Engineering Facilitates Invasions by Exotic Plants in High-Andean Ecosystems. J. Ecol. 2007, 95, 682-688. [CrossRef]

23. Aguiar, M.R.; Sala, O.E. Patch Structure, Dynamics and Implications for the Functioning of Arid Ecosystems. Trends Ecol. Evol. 1999, 14, 273-277. [CrossRef] 
24. Soriano, A.; Sala, O.; Perelman, S. Patch Structure and Dynamics in a Patagonian Arid Steppe. Vegetatio 1994, 111, 127-135. [CrossRef]

25. Aguiar, M.; Sala, O. Interactions among Grasses, Shrubs and Herbivores Patagonia. Ecol. Austral 1998, 8, $201-210$.

26. Armas, C.; Pugnaire, F.I.; Sala, O.E. Patch Structure Dynamics and Mechanisms of Cyclical Succession in a Patagonian Steppe (Argentina). J. Arid Environ. 2008, 72, 1552-1561. [CrossRef]

27. Tirado, R.; Pugnaire, F.I. Shrub Spatial Aggregation and Consequences for Reproductive Success. Oecologia 2003, 136, 296-301. [CrossRef] [PubMed]

28. Maestre, F.T.; Rodríguez, F.; Bautista, S.; Cortina, J.; Bellot, J. Spatial Associations and Patterns of Perennial Vegetation Ina Semi-Arid Steppe: A Multivariate Geostatistics Approach. Plant Ecol. 2005, 179, 133-147. [CrossRef]

29. Halpern, C.B.; Antos, J.A.; Rice, J.M.; Haugo, R.D.; Lang, L. Tree Invasion of a Montane Meadow Complex: Temporal Trends, Spatial Patterns, and Biotic Interactions. J. Veg. Sci. 2010, 21, 717-732. [CrossRef]

30. Kikvidze, Z.; Pugnaire, F.I.; Brooker, R.W.; Choler, P.; Lortie, C.J.; Michalet, R.; Callaway, R.M. Linking Patterns and Processes in Alpine Plant Communities: A Global Study. Ecology 2005, 86, 1395-1400. [CrossRef]

31. Pugnaire, F.; Haase, P.; Puigdefabregas, J.; Cueto, M.; Clarck, S.; Incoll, L. Facilitation and Succession under the Canopy of a Leguminous Shrub, Retama Sphaerocarpa, in a Semi-Arid Environment in South-East Spain. Oikos 1996, 76, 455-464. [CrossRef]

32. Benecke, U. The Invasive Potential of Lodgepole Pine. Tussock Grassl. Mt. Lands Inst. Rev. 1967, 13, 36-43.

33. Ledgard, N. The Spread of Lodgepole Pine (Pinus contorta, Dougl.) in New Zealand. For. Ecol. Manag. 2001, 141, 43-57. [CrossRef]

34. Richardson, D.M.; Bond, W.J. Determinants of Plant Distribution: Evidence from Pine Invasions. Am. Nat. 1991, 137, 639-668. [CrossRef]

35. Richardson, D.; Higgins, S. Pines as Invaders in the Southern Hemisphere. In Ecology and Biogeography of Pinus; Richardson, D., Ed.; Cambridge University Press: Cambridge, UK, 1998.

36. Despain, D.G. Dispersal Ecology of Lodgepole Pine (Pinus contorta Dougl.) in Its Native Environment as Related to Swedish Forestry. For. Ecol. Manag. 2001, 141, 59-68. [CrossRef]

37. Richardson, D.M.; Rejmánek, M.; Rejmanek, M. Conifers as Invasive Aliens: A Global Survey and Predictive Framework. Divers. Distrib. 2004, 10, 321-331. [CrossRef]

38. Rejmanek, M. Invasive Trees and Shrubs: Where Do They Come from and What We Should Expect in the Future? Biol. Invasions 2014, 16, 483-498. [CrossRef]

39. Gundale, M.J.; Pauchard, A.; Langdon, B.; Peltzer, D.A.; Maxwell, B.D.; Nuñez, M.A. Can Model Species Be Used to Advance the Field of Invasion Ecology? Biol. Invasions 2014, 16, 591-607. [CrossRef]

40. Food and Agriculture Organization of the United Nations. Global Forest Resources Assessment 2000 (FRA 2000); FAO Forestry Paper No 140; Food and Agriculture Organization of the United Nations: Rome, Italy, 2010.

41. Richardson, D.M.; Petit, R.J. Pines as Invasive Aliens: Outlook on Transgenic Pine Plantations in the Southern Hemisphere. In Landscapes, Genomics and Transgenic Conifers. Managing Forest Ecosystems; Springer: Dordrecht, The Netherlands, 2006; pp. 169-188. [CrossRef]

42. Peña, E.; Hidalgo, M.; Langdon, B.; Pauchard, A. Patterns of Spread of Pinus contorta Dougl. Ex Loud. Invasion in a Natural Reserve in Southern South America. For. Ecol. Manag. 2008, 256, 1049-1054. [CrossRef]

43. Engelmark, O.; Sjöberg, K.; Andersson, B.; Rosvall, O.; Ågren, G.I.; Baker, W.L.; Barklund, P.; Björkman, C.; Despain, D.G.; Elfving, B.; et al. Ecological Effects and Management Aspects of an Exotic Tree Species: The Case of Lodgepole Pine in Sweden. For. Ecol. Manag. 2001, 141, 3-13. [CrossRef]

44. Hepp, C. Praderas En La Zona Austral: XI Región (Aysén). In Praderas para Chile; Instituto de Investigaciones Agropecuarias (INIA): Santiago, Chile, 1996.

45. Ganderats, S. Antecedentes Sobre La Producción de Praderas En Aysen. In Boletín INIA-Instituto de Investigaciones Agropecuarias 69; INIA: Madrid, Spain, 2001.

46. Bravo-Monasterio, P.; Pauchard, A.; Fajardo, A. Pinus contorta Invasion into Treeless Steppe Reduces Species Richness and Alters Species Traits of the Local Community. Biol. Invasions 2016, 18, 1883-1894. [CrossRef]

47. Franzese, J.; Urrutia, J.; García, R.A.; Taylor, K.; Pauchard, A. Pine Invasion Impacts on Plant Diversity in Patagonia: Invader Size and Invaded Habitat Matter. Biol. Invasions 2017, 19, 1015-1027. [CrossRef]

48. Taylor, K.T.; Maxwell, B.D.; Pauchard, A.; Nuñez, M.A.; Rew, L.J. Native versus Non-Native Invasions: Similarities and Differences in the Biodiversity Impacts of Pinus contorta in Introduced and Native Ranges. Divers. Distrib. 2016, 22, 578-588. [CrossRef] 
49. Taylor, K.T.; Maxwell, B.D.; McWethy, D.B.; Pauchard, A.; Nuñez, M.A.; Whitlock, C. Pinus contorta Invasions Increase Wildfire Fuel Loads and May Create a Positive Feedback with Fire. Ecology 2017, 98, 678-687. [CrossRef] [PubMed]

50. Davis, K.T.; Maxwell, B.D.; Caplat, P.; Pauchard, A.; Nuñez, M.A. Simulation Model Suggests That Fire Promotes Lodgepole Pine (Pinus contorta) Invasion in Patagonia. Biol. Invasions 2019, 1. [CrossRef]

51. Langdon, B.; Pauchard, A.; Aguayo, M. Pinus contorta Invasion in the Chilean Patagonia: Local Patterns in a Global Context. Biol. Invasions 2010, 12, 3961-3971. [CrossRef]

52. Pauchard, A.; Escudero, A.; García, R.A.; de la Cruz, M.; Langdon, B.; Cavieres, L.A.; Esquivel, J. Pine Invasions in Treeless Environments: Dispersal Overruns Microsite Heterogeneity. Ecol. Evol. 2016, 447-459. [CrossRef]

53. Richardson, D.M. Plant Invasions. Encycl. Biodivers. 2001. [CrossRef]

54. Lotan, J.E.; Critchfield, W.B. Lodgepole Pine. In Silvics of North America; Burns, R.M., Honkala, B.H., Eds.; USDA Forest Service and Agriculture Hanbook N¹3; USDA: Washington, DC, USA, 1990; Volume 1, pp. 302-315. [CrossRef]

55. Pablo, U.; Aceituno, P.; Fuenzalida, H.; Rutllant, J.; Santibañez, F. Caracterizacion Climatica. In Perséctivas de Desarrollo de los Recursos de La Region Aisen del GEneral Carlos Ibañez del Campo; Intendencia Regional de Aysén: Coyhaique, Chile, 1979.

56. Gascón, A. Situación Forestal y Biodiversidad En La Región De Aysén; Informe técnico “Proyecto Fortalecimiento ciudadano en la Región de Aysen"; Ecosistemas y Fundacion Manfred Hermsen: Santiago-Coyhaique, Chile, 2005.

57. Schlesinger, W.H.; Whitford, W.G.; Virginia, R.A.; Huenneke, L.F.; Reynolds, J.F.; Jarrell, W.M.; Cunningham, G.L. Biological Feedbacks in Global Desertification. Science 2006, 247, 1043-1048. [CrossRef]

58. Maestre, F.T.; Valladares, F.; Reynolds, J.F. Is the Change of Plant-Plant Interactions with Abiotic Stress Predictable? A Meta-Analysis of Field Results in Arid Environments. J. Ecol. 2005, 93, 748-757. [CrossRef]

59. Schleicher, J.; Wiegand, K.; Ward, D. Changes of Woody Plant Interaction and Spatial Distribution between Rocky and Sandy Soil Areas in a Semi-Arid Savanna, South Africa. J. Arid Environ. 2011, 75, 270-278. [CrossRef]

60. López, R.P.; Larrea-Alcázar, D.; Zenteno-Ruiz, F. Spatial Pattern Analysis of Dominant Species in the Prepuna: Gaining Insight into Community Dynamics in the Semi-Arid, Subtropical Andes. J. Arid Environ. 2010, 74, 1534-1539. [CrossRef]

61. Ramsay, P.M.; Fotherby, R.M. Implications of the Spatial Pattern of Vigur's Eyebright (Euphrasia Vigursii) for Heathland Management. Basic Appl. Ecol. 2007, 8, 242-251. [CrossRef]

62. Wiegand, T.; Kissling, W.D.; Cipriotti, P.A.; Aguiar, M.R. Extending Point Pattern Analysis for Objects of Finite Size and Irregular Shape. J. Ecol. 2006, 94, 825-837. [CrossRef]

63. Wiegand, T.; Moloney, K.A. Rings, Circles, and Null-Models for Point Pattern Analysis in Ecology. Oikos 2004, 104, 209-229. [CrossRef]

64. Wiegand, T.; Moloney, K.A. Handbook of Spatial Point-Pattern Analysis in Ecology, 1st ed.; Chapman and Hall/CRC: Boca Raton, FL, USA, 2013.

65. Haase, P. Spatial Pattern Analysis in Ecology Based on Ripley's K-Function: Introduction and Methods of Edge Correction. J. Veg. Sci. 2006, 6, 575-582. [CrossRef]

66. Callaway, R. Positive Interactions and Interdependence in Plant Communities; Springer International Publishing: Dordrecht, The Netherlands, 2007.

67. Ledgard, N.J. Wilding Conifers-New Zealand History and Research Background. In Managing Wilding Conifers in New Zealand-Present and Future; New Zealand Plant Protection Society: Christchurch, New Zealand, 2004; pp. 1-25.

68. Cattaneo, M. Effects of Microsite Characteristics, Competition and Grazing on Pinus contorta Dougl. and Pseudotsuga menziesii (Mirb.) Franco Seedling Establishment. Master's Thesis, University of Canterbury, Christchurch, New Zealand, 2002; pp. 1-306.

69. Allen, R.B.; Lee, W.G. Seedling Establishment Microsites of Exotic Conifers in Chionochloa Rigida Tussock Grassland, Otago, New Zealand. N. Z. J. Bot. 1989, 27, 491-498. [CrossRef]

70. Bullock, J.M. A Long-Term Study of the Roles of Competition and Facilitation in the Establishment of an Invasive Pine Following Heathland Fires. J. Ecol. 2009, 97, 646-656. [CrossRef]

71. Miriti, M.N. Twenty Years of Changes in Spatial Association and Community Structure among Desert Perennials. Ecology 2007, 88, 1177-1190. [CrossRef] 
72. Callaway, R.M.; Walker, L.R. Competition and Facilitation: A Synthetic Approach to Interactions in Plant Communities. Ecology 1997, 78, 1958-1965. [CrossRef]

73. Davis, M.R. Establishment of Conifer Plantations in the South Island High Country by Direct drilling. N. Z. For. 1989, 34, 21-24.

(C) 2019 by the authors. Licensee MDPI, Basel, Switzerland. This article is an open access article distributed under the terms and conditions of the Creative Commons Attribution (CC BY) license (http://creativecommons.org/licenses/by/4.0/). 